\title{
Correlation between praecordial accelerocardiogram and left ventricular pressure
}

\author{
Leslie Hume', ${ }^{1,2}$, Arthur H. Kitchin, and Stuart R. Reuben \\ The Department of Medicine, Western General Hospital, Edinburgh EH4 $2 \mathrm{XU}$
}

The praecordial accelerocardiogram possesses important practical advantages over more familiar techniques of recording praecordial pulsations. We have compared the amplitude of the $P$ wave of the praecordial accelerocardiogram in 6 normal subjects (group 1) and 21 patients with heart disease (group 2) at rest and after 3 minutes of isometric handgrip at 30 per cent maximum voluntary contraction.

At rest in group 2 there was a significant linear correlation between the amplitude of the $P$ wave of the accelerocardiogram, relative to the maximum systolic amplitude $(P / D E)$, and the left ventricular enddiastolic pressure $(P<0 \cdot 01)$. However, comparison of the data for $P / D E$ showed that the mean value ( \pm SEM) of $29 \pm 5$ per cent in group 1 was not significantly different from the mean value of $37 \pm 4$ per cent in group $2(P>0 \cdot 30)$.

During handgrip the mean amplitude of the $P$ wave did not increase significantly in group $1(P>0 \cdot 20)$ but increased significantly in group $2(P<0.02)$. In group 2 there was a significant linear correlation between the percentage increase in the amplitude of the $P$ wave of the accelerocardiogram during handgrip and the percentage increase in the left ventricular end-diastolic pressure $(P<0.01)$.

An abnormal increase in left ventricular filling pressure during a stress test is a sensitive indicator of the presence of heart disease (Amende et al., 1972; Fisher et al., 1973; Grossman et al., 1973; Helfant, DeVilla, and Meister, 1971; Kivowitz et al., 1971; Krayenbuehl et al., 1972; Parker, Di Giorgi, and West, 1966; Quinones et al., 1974; Wiener, Dwyer, and Cox, 1968). It would be valuable if this pathological response could be detected by noninvasive techniques that could be used in screening programmes. Various workers have described the appearance of accentuation of a fourth heart sound on the phonocardiogram (Aronow et al., 1971; Cohn et al., 1973; Siegel et al., 1972) and an increase in the amplitude of the 'a' wave of the apex cardiogram (Benchimol and Dimond, 1962; Dimond and Benchimol, 1963; Ginn et al., 1967; Rios and Massumi, 1965; Siegel et al., 1972) during acutely stressful manoeuvres. However, technically satisfactory apex cardiograms may be difficult to record in some patients, while conventional phonocardiography is not a quantitative technique Received 15 September 1975.

1Present address: Deaconess Hospital, Edinburgh.

${ }^{2}$ In receipt of an Edinburgh University Graduate Research Scholarship. and its value in this context is therefore somewhat limited.

The praecordial accelerocardiogram, which measures the instantaneous acceleration of praecordial movement throughout the cardiac cycle, bears a close similarity in its configuration to the low frequency phonocardiogram (Luisada, 1962) and has been used for this purpose in children (Bew et al., 1971). It differs from the phonocardiogram in that it has a linear response from DC to $25 \mathrm{~Hz}$. It also has the important practical advantage of being relatively insensitive to respiratory movements (Luisada, 1962; Reuben and Littler, 1973; Rosa and Kaplan, 1960). Furthermore, the positioning of the transducer and patient is not as critical as with the apex cardiogram (Reuben and Littler, 1973). Measurement of the amplitude of the systolic waves of the praecordial accelerocardiogram has previously been shown to provide valuable information about left ventricular systolic performance (Hume, Irving, and Reuben, 1974; Reuben and Littler, 1973). We were therefore interested to see if we could detect changes in the diastolic properties of the left ventricle by this simple, non-invasive technique. 


\section{Subjects and methods}

Our subjects comprised 6 healthy, normal volunteer members of the staff (group 1) and 21 patients with heart disease (group 2), 8 of whom had aortic stenosis, 11 had coronary artery disease, and 2 had congestive cardiomyopathy. All were in sinus rhythm and none had clinical or haemodynamic evidence of mitral valve disease. Two patients had mild aortic regurgitation in addition to aortic stenosis, 7 had sustained previous myocardial infarction and 4 had evidence of dyskinesis on biplane left ventricular cineangiography. Only one patient was in clinical cardiac failure at the time of the study. Of the patients with aortic stenosis 5 had electrocardiographic evidence of left ventricular hypertrophy. In these patients the mean $( \pm$ SEM) aortic valve gradient was $58( \pm 10) \mathrm{mmHg}(7 \cdot 7 \pm 1 \cdot 31$ $\mathrm{kPa})$, the mean cardiac index was $2.91( \pm 0.30) 1 /$ min per $\mathrm{m}^{2}$, and the mean aortic valve area was $0.62( \pm 0.10)$ $\mathrm{cm}^{2}$. In the patients with coronary artery disease 3vessel disease was present in 7 cases, 2-vessel disease in 2 cases, and single-vessel disease in 2 cases. The mean $( \pm$ SEM) age of the subjects in group 1 was $30( \pm 1)$ and in group $2,52( \pm 3)$ years.

The accelerocardiogram transducer, whose physical characteristics have been fully described (Bew et al., 1971; Reuben and Littler, 1973), was attached to the chest wall overlying the fifth rib internal to the apex beat by means of an adhesive disc. An electrocardiogram recorded from praecordial leads was displayed simultaneously with the accelerocardiogram on an ultraviolet recorder (Honeywell Recording Oscillograph, Type 1185, Mark 2). All recordings were made during normal
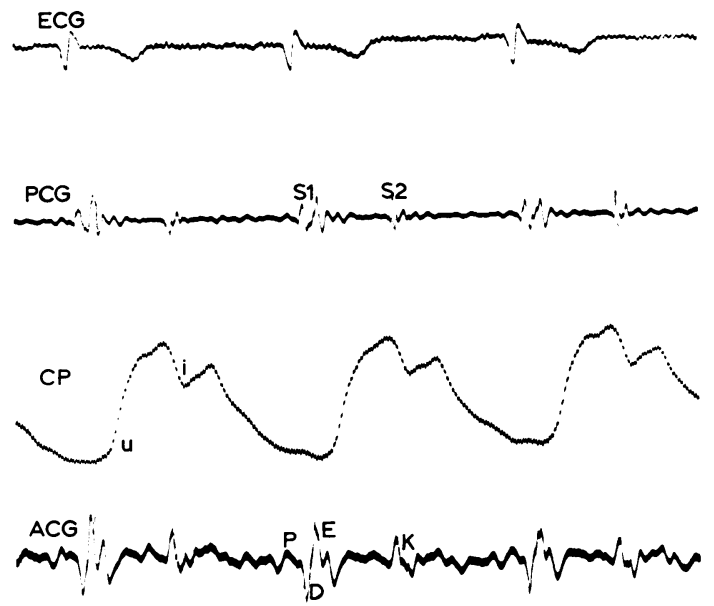

FIG. 1 Example of accelerocardiogram tracing. From above: $E C G=$ electrocardiogram; $P C G=$ phonocardiogram; $C P=$ carotid pulse; $A C G=a c-$ celerocardiogram (labelled according to Rosa et al., 1961). The accelerocardiogram is of small amplitude to accommodate the phonocardiogram and carotid pulse. respiration with the subjects supine. Heart rate was calculated from the average of 10 consecutive $R R$ intervals measured at a paper speed of $100 \mathrm{~mm} / \mathrm{s}$, and the amplitude of the $\mathbf{P}$ wave of the accelerocardiogram (Fig. 1) was also averaged over 10 cardiac cycles, each measured to the nearest millimetre, at a paper speed of $25 \mathrm{~mm} / \mathrm{s}$.

The tracings of group 1 were measured independently by 2 observers and no significant differences in the mean amplitude of the $\mathbf{P}$ wave occurred in any individual. For convenience, the accelerocardiographic data were expressed in microvolts, using a 0.5 millivolt square wave as a standard. No attempt was made to calibrate the tracings in units of acceleration, because variations in chest wall thickness, transducer coupling, and the position of the heart renders comparison of absolute values between subjects meaningless (Reuben and Littler, 1973). Following the convention of apex cardiography, the ratio of the amplitude of the $P$ wave relative to the maximum systolic deflection $\left(P_{/} \mathbf{D E}\right)$ was used in comparisons of resting data (Benchimol and Dimond, 1962; Gibson et al., 1974; Ginn et al., 1967; Voigt and Friesinger, 1970).

The patients in group 2 were studied during diagnostic cardiac catheterization after the collection of resting haemodynamic data but before angiographic studies. Beta-adrenergic blocking drugs were discontinued 72 hours before catheterization but all other drugs were administered as usual up to the time of the procedure. One hour before catheterization the patients were sedated with $5 \mathrm{mg}$ diazepam (Valium, Roche) orally. In the patients with aortic stenosis left ventricular pressure was recorded by means of a Brockenbrough catheter following transseptal catheterization of the left atrium, while central aortic pressure was measured by means of a polythylene catheter $100 \mathrm{~cm}$ in length with an internal diameter of $0.066 \mathrm{~cm}$ (Formocath, BectonDickinson Ltd.) introduced into the right femoral artery by the Seldinger technique. The frequency response of the catheter-manometer system was flat to $20 \mathrm{~Hz}$. In the remaining patients only left ventricular pressure was measured by retrograde catheterization from the right femoral artery.

Left ventricular maximum $\mathrm{dp} / \mathrm{dt}$ was obtained by electronic differentiation of the pressure signal, using an RC filter network whose response was uniform to $50 \mathrm{~Hz}$. Resting cardiac output was measured by the indicator dilution method, using indocyanine green as the indicator and a Waters $\times 300$ cuvette densitometer. Mean simultaneous aortic valve gradient was measured at rest and the valve area was calculated from Gorlin's formula (Gorlin and Gorlin, 1951). We used sustained isometric handgrip as a means of inducing an acute increase in left ventricular diastolic pressure, as described by previous workers (Amende et al., 1972; Cohn et al., 1973; Fisher et al., 1973; Grossman et al., 1973; Helfant et al., 1971; Kivowitz et al., 1971; Krayenbuehl et al., 1972; Quinones et al., 1974).

In the subjects of group 1, who did not undergo cardiac catheterization, handgrip was performed using a standard strain gauge dynanometer, and blood pressure was measured by sphygmomanometry, while in the 
patients of group 2 a partially inflated sphygmomanometer cuff was used. Each subject's maximum grip strength was first determined and each was then instructed to maintain 30 per cent maximum voluntary contraction for 3 minutes, a level of isometric exercise which has previously been shown to elicit consistent increases in heart rate and blood pressure (Fisher et al., 1973; Kivowitz et al., 1971; Quinones et al., 1974). Care was taken to ensure that the subjects did not perform a Valsalva manoeuvre, as has been emphasized in previous studies (Fisher et al., 1973; Helfant et al., 1971). In the patients of group 2 peak left ventricular systolic pressure, post ' $a$ ' wave left ventricular enddiastolic pressure, and the amplitude of the ' $a$ ' wave, aortic systolic, and diastolic pressures, and left ventricular maximum dp/dt were recorded on an ultraviolet recorder (Shandon Southern Instruments Ltd., U.K.) simultaneously with the praecordial accelerocardiogram. Recordings were made before, during the final 30 seconds of, and 4 minutes after handgrip.

The results for the individual and for the group are expressed as the mean value \pm 1 SEM. Statistical analysis was performed by Student's paired and unpaired $t$ test using a PDP 11/10 computer (Digital Equipment Corporation, Maynard, Massachusetts).

\section{Results}

The results are summarized in Tables 1 to 3 and in Figs. 2 and 3.

TABLE 1 Resting (control) data and effects of handgrip in normal subjects

\begin{tabular}{|c|c|c|c|c|c|c|}
\hline \multicolumn{2}{|l|}{ Subject } & \multirow{2}{*}{$\begin{array}{l}\begin{array}{l}\text { Heart } \\
\text { rate } \\
\text { (beats/ } \\
\text { min) }\end{array} \\
64 \\
75\end{array}$} & \multirow{2}{*}{$\begin{array}{l}\begin{array}{l}L V \\
\text { systolic }\end{array} \\
\begin{array}{c}\text { pressure } \\
\text { ( } \mathrm{mmHg} \text { (Hg }\end{array} \\
118 \\
150\end{array}$} & $\begin{array}{l}\text { Ao } \\
\text { diastolic } \\
\text { pressure } \\
\text { ( } m m \mathrm{mg})\end{array}$ & $\stackrel{P}{f(\mu V)}$ & \multirow{2}{*}{$\begin{array}{l}P / D E \\
(\%)\end{array}$} \\
\hline 1 & $\begin{array}{l}\text { Control } \\
\text { Handgrip }\end{array}$ & & & $\begin{array}{l}75 \\
90\end{array}$ & $\begin{array}{l}155(7) \\
179(19)\end{array}$ & \\
\hline 2 & $\begin{array}{l}\text { Control } \\
\text { Handgrip }\end{array}$ & $\begin{array}{l}66 \\
82\end{array}$ & $\begin{array}{l}110 \\
130\end{array}$ & $\begin{array}{l}80 \\
95\end{array}$ & $\begin{array}{l}148(4) \\
216(10)\end{array}$ & 23 \\
\hline 3 & $\begin{array}{l}\text { Control } \\
\text { Handgrip }\end{array}$ & $\begin{array}{r}82 \\
85\end{array}$ & $\begin{array}{l}118 \\
130\end{array}$ & $\begin{array}{l}74 \\
90\end{array}$ & $\begin{array}{l}224(9) \\
196(11)\end{array}$ & $33(2)$ \\
\hline 4 & $\begin{array}{l}\text { Control } \\
\text { Handgrip }\end{array}$ & $\begin{array}{r}59 \\
075\end{array}$ & $\begin{array}{l}115 \\
145\end{array}$ & $\begin{array}{r}90 \\
105\end{array}$ & $\begin{array}{l}182(11) \\
178(9)\end{array}$ & 50 (3) \\
\hline 5 & $\begin{array}{l}\text { Control } \\
\text { Handgrip }\end{array}$ & $\begin{array}{r}69 \\
71\end{array}$ & $\begin{array}{r}90 \\
110\end{array}$ & $\begin{array}{l}55 \\
70\end{array}$ & $\begin{array}{l}169(11) \\
200(11)\end{array}$ & $19(1)$ \\
\hline 6 & $\begin{array}{l}\text { Control } \\
\text { Handgrip }\end{array}$ & $\begin{array}{r}71 \\
85\end{array}$ & $\begin{array}{l}130 \\
160\end{array}$ & $\begin{array}{l}95 \\
95\end{array}$ & $\begin{array}{l}220(12) \\
228(15)\end{array}$ & 26 \\
\hline Group & $\begin{array}{l}\text { Control } \\
\text { Handgrip }\end{array}$ & $\begin{array}{r}68(3) \\
\mathrm{p} 78(2)\end{array}$ & $\begin{array}{l}114(5) \\
139(7)\end{array}$ & $\begin{array}{l}78(6) \\
91(5)\end{array}$ & $\begin{array}{l}183(13) \\
200(8)\end{array}$ & 29 \\
\hline $\begin{array}{l}\% \mathrm{Cl} \\
\mathbf{P}\end{array}$ & & $\begin{array}{l}+13(3) \\
<0.005\end{array}$ & $\begin{array}{r}+21(2) \\
<0.001\end{array}$ & $\begin{array}{c}+18(4) \\
<0.02\end{array}$ & $\begin{array}{c}+11.5(8) \\
>0.20\end{array}$ & - \\
\hline
\end{tabular}

Figures in parentheses represent one standard error of the mean for the individual and for the group.

Conversion from Traditional to SI units: $1 \mathrm{mmHg} \approx 0.133 \mathrm{kPa}$

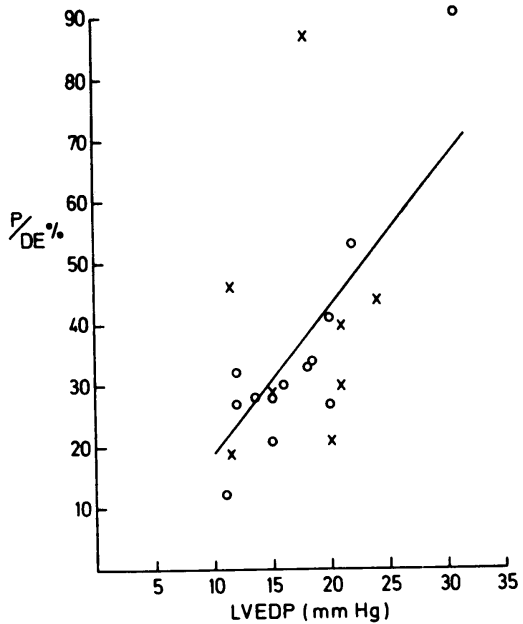

FIG. 2 Correlation between $P / D E$ and left ventricular end-diastolic pressure at rest. Crosses represent patients with aortic stenosis. Circles represent patients with myocardial disease.

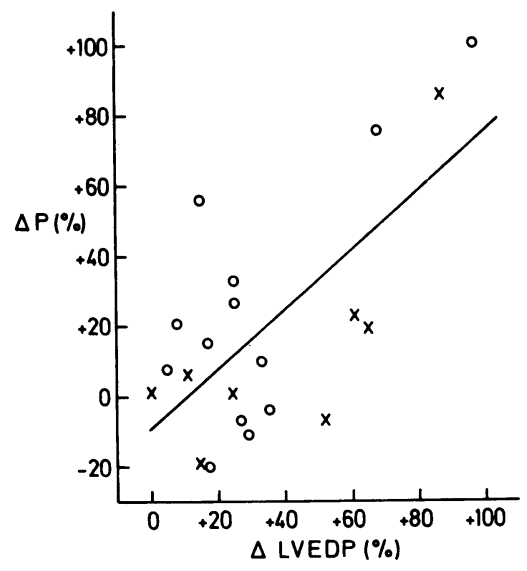

FIG. 3 Correlation between the percentage change in the amplitude of the $P$ wave during handgrip and the percentage change in left ventricular end-diastolic pressure. Crosses represent patients with aortic stenosis. Circles represent patients with myocardial disease.

TABLE 3 Regression data in Group 2

\begin{tabular}{llll}
\hline & Regression equation & $\begin{array}{c}\text { Correlation } \\
\text { coefficient }\end{array}$ & $\begin{array}{l}P \\
\text { value }\end{array}$ \\
\hline P/DE v LVEDP & $\begin{array}{l}\mathrm{P} / \mathrm{DE}= \\
2.4 \times \text { LVEDP-5.7 }\end{array}$ & 0.60 & $<0.01]$ \\
$\triangle \mathrm{P}$ & $\mathrm{V} \triangle \mathrm{LVEDP}$ & $\begin{array}{l}\triangle \mathrm{P}= \\
0.85 \times \triangle \mathrm{LVEDP}-9\end{array}$ & $<0.01$ \\
& & \\
\hline
\end{tabular}


TABLE 2 Resting (control) data and effects of handgrip in patients with heart disease

\begin{tabular}{|c|c|c|c|c|c|c|c|c|}
\hline Subject & & $\begin{array}{l}\text { Heart } \\
\text { rate } \\
\text { (beats/min) }\end{array}$ & $\begin{array}{l}\text { LV syst. } \\
\text { pressure } \\
\text { (mmHg) }\end{array}$ & $\begin{array}{l}\text { Ao diast. } \\
\text { pressure } \\
(\mathrm{mmHg})\end{array}$ & $\begin{array}{l}L V \max . \\
d p / d t \\
(m m H g / s)\end{array}$ & $\begin{array}{l}\text { LV end-diast. } \\
\text { pressure } \\
\text { (mmHg) }\end{array}$ & $\begin{array}{l}P \\
(\mu V)\end{array}$ & $\begin{array}{l}P / D E \\
(\%)\end{array}$ \\
\hline \multirow[t]{2}{*}{8} & Control & 60 & 210 & 95 & $\begin{array}{l}2540 \\
1890\end{array}$ & $\begin{array}{l}23 \\
24\end{array}$ & $\begin{array}{l}185(10) \\
158(6)\end{array}$ & $44(3)$ \\
\hline & Handgrip & 79 & 240 & 120 & 3040 & 45 & 293 (13) & $27(J)$ \\
\hline \multirow[t]{2}{*}{9} & Control & 94 & 203 & 75 & 1600 & 18 & $184(6)$ & $87(3)$ \\
\hline & Handgrip & 98 & 215 & 85 & 1800 & 20 & 200 (16) & \\
\hline \multirow[t]{2}{*}{10} & Control & 65 & 120 & 70 & 1330 & $11 \cdot 5$ & $140(6)$ & $19(1)$ \\
\hline & Handgrip & 73 & 160 & 87 & 1550 & 19 & 167 (13) & \\
\hline \multirow[t]{2}{*}{11} & Control & 111 & 210 & 80 & 1560 & 21 & $220(13)$ & $30(3)$ \\
\hline & Handgrip & 114 & 215 & 97 & 1900 & 32 & $204(22)$ & \\
\hline \multirow[t]{2}{*}{12} & Control & 72 & 220 & 65 & 500 & $11 \cdot 5$ & 205 (3) & $46(2)$ \\
\hline & Handgrip & 81 & 258 & 75 & 620 & $18 \cdot 5$ & $253(10)$ & \\
\hline \multirow[t]{2}{*}{13} & Control & 63 & 233 & 78 & 1450 & 21 & $183(5)$ & $40(1)$ \\
\hline & Handgrip & 68 & 250 & 84 & 1650 & 26 & $184(12)$ & \\
\hline \multirow[t]{2}{*}{14} & Control & 81 & 240 & 90 & 1820 & 15 & $184(12)$ & $29(2)$ \\
\hline & Handgrip & 83 & 250 & 100 & 1960 & 15 & $187(12)$ & \\
\hline \multirow[t]{2}{*}{15} & Control & 47 & 135 & - & 2000 & 20 & $254(22)$ & $27(1)$ \\
\hline & Handgrip & 58 & 175 & - & 2000 & 21 & $276(20)$ & \\
\hline \multirow[t]{2}{*}{16} & Control & 60 & 190 & - & 1780 & 15 & $143(7)$ & $29(1)$ \\
\hline & Handgrip & 62 & 215 & - & 1930 & 20 & 158 (14) & \\
\hline \multirow[t]{2}{*}{17} & Control & 81 & 160 & - & 960 & $18 \cdot 5$ & $243(16)$ & $34(2)$ \\
\hline & Handgrip & 88 & 180 & - & 1060 & 25 & 234 (13) & \\
\hline \multirow[t]{2}{*}{18} & Control & 65 & 125 & 一 & 1820 & 15 & $121(3)$ & $21(1)$ \\
\hline & Handgrip & 90 & 168 & - & 2180 & $29 \cdot 5$ & $245(16)$ & \\
\hline \multirow[t]{2}{*}{19} & Control & 53 & 125 & - & 1120 & 16 & $110(3)$ & $30(2)$ \\
\hline & Handgrip & 57 & 140 & - & 1250 & 20 & $140(8)$ & \\
\hline \multirow[t]{2}{*}{20} & Control & 76 & 125 & - & 2360 & 18 & $210(10)$ & $33(2)$ \\
\hline & Handgrip & 82 & 148 & - & 2800 & 21 & $242(17)$ & \\
\hline \multirow[t]{2}{*}{21} & Control & 61 & 120 & 一 & 2150 & 11 & $115(4)$ & $12(1)$ \\
\hline & Handgrip & 71 & 157 & - & 3170 & $18 \cdot 5$ & $202(22)$ & \\
\hline \multirow[t]{2}{*}{22} & Control & 76 & 120 & - & 870 & 22 & 251 (10) & $53(3)$ \\
\hline & Handgrip & 80 & 130 & 一 & 1000 & 28 & 234 (11) & \\
\hline \multirow[t]{2}{*}{23} & Control & 110 & - & - & 1100 & 31 & 377 (23) & 91 (3) \\
\hline & Handgrip & 113 & 一 & 一 & 1150 & 40 & 335 (15) & \\
\hline \multirow[t]{2}{*}{24} & Control & 81 & 117 & - & 1390 & $13 \cdot 5$ & $135(7)$ & $28(2)$ \\
\hline & Handgrip & 85 & 137 & - & 1530 & $15 \cdot 5$ & $210(29)$ & \\
\hline \multirow[t]{2}{*}{25} & Control & 67 & 130 & - & 1850 & 20 & $208(9)$ & $41(3)$ \\
\hline & Handgrip & 68 & 135 & - & 1790 & 25 & 277 (18) & \\
\hline \multirow[t]{2}{*}{26} & Control & 70 & 112 & - & 1190 & 12 & $153(5)$ & $27(1)$ \\
\hline & Handgrip & 78 & 140 & - & 1300 & 14 & $123(5)$ & \\
\hline \multirow[t]{2}{*}{27} & Control & 76 & 120 & - & 1840 & 12 & $120(5)$ & $32(3)$ \\
\hline & Handgrip & 87 & 140 & - & 2780 & 13 & $145(8)$ & \\
\hline Group & Control & 74 (4) & $159(10)$ & $80(4)$ & $1545(100)$ & $17(1)$ & $188(14)$ & $37(4)$ \\
\hline$\%$ Change & Handgrip & $\begin{array}{c}81(3) \\
+9(1.5)\end{array}$ & $\begin{array}{r}182(10) \\
+16(2)\end{array}$ & $\begin{array}{r}93(5) \\
+16(3)\end{array}$ & $\begin{array}{l}1855(155) \\
+19(3.5)\end{array}$ & $23(2)$ & 214 (12) & \\
\hline $\begin{array}{l}\mathrm{P} \\
\mathrm{P}\end{array}$ & & $\begin{array}{l}+9(1.5) \\
<0.001\end{array}$ & $\begin{array}{c}+16(2) \\
<0.001\end{array}$ & $\begin{array}{l}+16(3) \\
<0.001\end{array}$ & $\begin{array}{l}+19(3.5) \\
<0.001\end{array}$ & $\begin{array}{r}+34(6) \\
<0.001\end{array}$ & $\begin{array}{c}+20(7) \\
<0.02\end{array}$ & - \\
\hline
\end{tabular}

Figures in parentheses represent one standard error of the mean for the individual and for the group.

\section{Resting data}

In our patient groups a significant linear correlation existed between P/DE and left ventricular enddiastolic pressure at rest (Fig. 2, Table 3), this being largely because of an extremely good correlation in the patients with myocardial disease. When the height of the left ventricular ' $a$ ' wave was substituted for end-diastolic pressure no improvement in this correlation was observed. Though the average ratio $P / D E$ in group 1 was $29 \pm 5$ per cent (Table 1) compared with $37 \pm 4$ per cent in group 2 (Table 2), these were not significantly different $(\mathrm{P}>0.30)$.

\section{Handgrip}

The haemodynamic effects of handgrip in the individual and in the groups as a whole are summarized in Tables 1 and 2. There were no signi- 
ficant differences between the groups as regards the percentage change in heart rate $(P>0.20)$, systolic pressure $(P>0.30)$, or aortic diastolic pressure $(P>0.80)$.

In Group 2 the mean left ventricular enddiastolic pressure increased from 17 to $23 \mathrm{mmHg}$ $(2.3$ to $3.1 \mathrm{kPa}$ ), a change of $34 \pm 6$ per cent (Table $2)$. This change was significant $(P<0.001)$.

In the normal subjects of group 1 the mean amplitude of the $P$ wave of the accelerocardiogram increased from 183 to 200 microvolts during handgrip, a change of $11.5 \pm 8$ per cent (Table 1 ), which was not significant $(P>0 \cdot 20)$ (Table 1$)$. In group 2 the amplitude of the $P$ wave increased from 188 to 214 microvolts (Table 2), a change of $20 \pm 7$ per cent (Table 2), which was significant $(P<0.02)$. However, the difference between the groups in the increase in the amplitude of the $P$ wave during handgrip was not significant $(P>0.30)$.

A significant linear correlation existed between the percentage changes in $\mathbf{P}$ and end-diastolic pressure during handgrip in group 2 (Fig. 3, Table $3)$. The correlation was not improved by substituting the percentage change in the height of the ' $a$ ' wave for the percentage change in end-diastolic pressure.

\section{Discussion}

The $P$ wave of the praecordial accelerocardiogram has been shown to occur simultaneously with atrial systole (Luisada, 1962; Mounsey, 1959; Rosa and Kaplan, 1960; Rosa et al., 1961), and its amplitude has been shown to be increased in patients with a fourth heart sound (Mounsey, 1957) and left ventricular hypertrophy (Mounsey, 1959). However, this previous work was subjectively based while the results reported in this study represent the first quantitative evaluation of the diastolic waves of the accelerocardiogram.

We have shown a linear correlation between $\mathrm{P} / \mathrm{DE}$ and left ventricular end-diastolic pressure (Table 3, Fig. 2), with a correlation coefficient $(r=0.60)$ similar to that described in previous work with the apex cardiogram (Gibson et al., 1974). In general only a moderate correlation between the ' $a$ ' wave of the apex cardiogram and left ventricular end-diastolic pressure has been demonstrable, and this has been attributed to a variety of factors. Firstly, the amplitude of the ' $a$ ' wave of the apex cardiogram depends on the contribution which atrial systole makes to left ventricular end-diastolic pressure (Benchimol and Dimond, 1962; Dimond and Benchimol, 1963; Voigt and Friesinger, 1970). However, in the present study the correlation

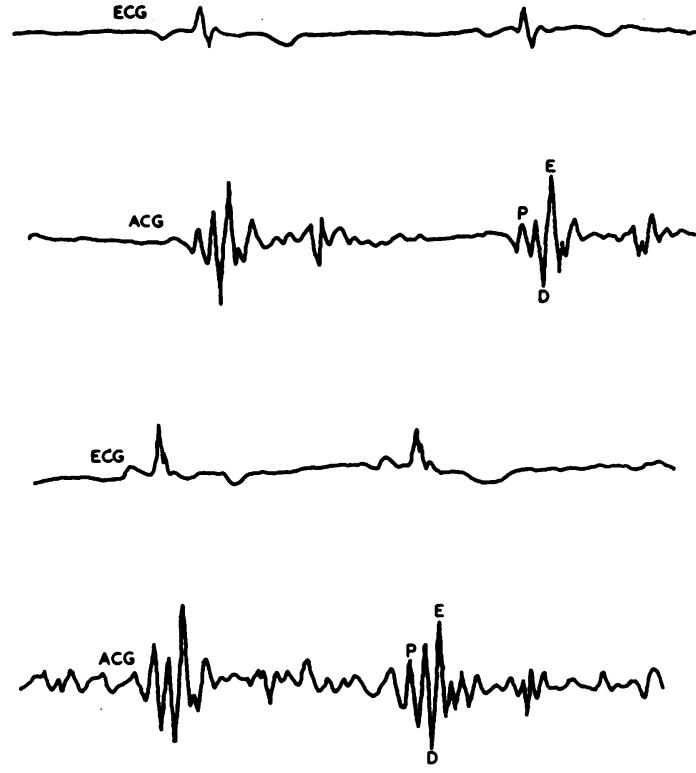

FIG. 4 Example showing the increase in the amplitude of the $P$ wave of the accelerocardiogram during handgrip. Top pair of records=control; lower pair= handgrip. In this example the amplitude of the $P$ wave (measured from trough to peak) increased by 85 per cent.

was not improved when the amplitude of the left ventricular ' $a$ ' wave was substituted for end-diastolic pressure. Secondly, the transmission of diastolic pressure waves through the chest wall depends on left ventricular wall stiffness and tension (Benchimol and Dimond, 1962; Cohn et al., 1973; Gibson et al., 1974; Mounsey, 1959; Rios and Massumi, 1965; Siegel et al., 1972; Voigt and Friesinger, 1970) which influence the relation between diastolic pressure and praecordial pulsations, particularly in a heterogeneous group of patients, some of whom have left ventricular hypertrophy or dyskinesis.

Finally, in patients with left ventricular dilatation changes in the mechanical coupling between heart and chest wall might modify the relation between praecordial pulsations and end-diastolic pressure.

Although the average ratio $\mathrm{P} / \mathrm{DE}$ in the patients was greater than that in the group of normal subjects (Tables 1 and 2), the variability within the groups was such that this was not significant $(P>0.30)$.

The increases in heart rate, blood pressure, left ventricular maximum $\mathrm{dp} / \mathrm{dt}$, and end-diastolic pressure, which we observed in our subjects during handgrip (Tables 1 and 2), are similar to those described in previous work (Fisher et al., 1973; 
Grossman et al., 1973; Helfant et al., 1971; Kivowitz et al., 1971; Krayenbuehl et al., 1972). Furthermore, the increases in heart rate and blood pressure during handgrip were similar in each of our groups, suggesting that the intensity of the stress was comparable.

The amplitude of the $\mathbf{P}$ wave of the accelerocardiogram increased during handgrip in both groups. This was significant for the patients as a whole $(P<0.02)$ but not for our normal control subjects $(P>0 \cdot 20)$ (Tables 1 and 2). However, we have failed to show a statistically significant difference between the groups as regards the increase in the amplitude of the $P$ wave during handgrip $(P>0.30)$. This might be caused, in part, by the small number of subjects studied. A better separation might also have been achieved if a more intense level of exercise had been employed. We feel, however, that the major factor accounting for our inability to discriminate between the groups is that we were compelled to express the changes in the amplitude of the $P$ wave during handgrip in terms of a percentage, rather than in absolute units. The haemodynamic counterpart of this is obviously the percentage change in end-diastolic pressure. However, the same percentage change in enddiastolic pressure may signify a normal response in subjects with a normal resting level and an abnormal response in subjects whose end-diastolic pressure is raised at rest.

The mean increase in the amplitude of the $P$ wave of 11.5 per cent during handgrip in the normal subjects is equivalent to a 24 per cent increase in left ventricular end-diastolic pressure (from regression equation, Table 3) which, from a normal resting level, is compatible with the increases in end-diastolic pressure observed by other workers in normal subjects during handgrip (Grossman et al., 1973; Helfant et al., 1971; Krayenbuehl et al., 1972; Quinones et al., 1974).

An increase in the amplitude of the ' $a$ ' wave of the apex cardiogram may be attributed either to an increase in the force of atrial contraction consequent upon a reduction in left ventricular end-diastolic distensibility or to an increase in left ventricular volume (Benchimol and Dimond, 1962; Gibson et al., 1974; Rios and Massumi, 1965; Siegel et al., 1972; Voigt and Friesinger, 1970). Whether the increase in left ventricular filling pressure which occurs during handgrip is the result of an acute change in compliance or of dilatation of the ventricle, caused by acute left ventricular failure, is uncertain (Fisher et al., 1973; Grossman et al., 1973; Siegel et al., 1972). An increase in left ventricular size during handgrip in patients with severe myocardial disease has recently been shown (Ludbrook,
Karliner, and O'Rourke, 1974), in contrast to the lack of change in normal subjects (Ludbrook et al., 1974; Stefadouros et al., 1974), which suggests that the increase in end-diastolic pressure in some patients may be caused, at least in part, by acute left ventricular failure. Our results, of course, do not shed any light on the mechanisms that underlie the increases in filling pressure and the amplitude of the $\mathbf{P}$ wave of the praecordial accelerocardiogram during handgrip, but they do suggest that accelerocardiography might be useful in monitoring changes in left ventricular end-diastolic pressure in serial studies or in response to acute interventions.

\section{References}

Amende, I., Krayenbuehl, H. P., Rutishauser, W., and Witz, P. (1972). Left ventricular dynamics during handgrip. British Heart fournal, 34, 688.

Aronow, W. S., Uyeyama, R. R., Cassidy, J., and Nebolon, J. (1971). Resting and post-exercise phonocardiogram and electrocardiogram in patients with angina pectoris and in normal subjects. Circulation, 43, 273.

Benchimol, A., and Dimond, E. G. (1962). The apex cardiogram in ischaemic heart disease. British Heart fournal, 24, 581 .

Bew, F. E., Pickering, D., Sleight, P., and Stott, F. D. (1971). 'Pixie' cardiography. Accelerometer applications to phonocardiography and displacement cardiography in childhood. British Heart fournal, 33, 702.

Cohn, P. F., Thompson, P., Strauss, W., Todd, J., and Gorlin, R. (1973). Diastolic heart sounds during static (handgrip) exercise in patients with chest pain. Circulation, 47, 1217.

Dimond, E. G., and Benchimol, A. (1963). Correlation of intracardiac pressure and praecordial movement in ischaemic heart disease. British Heart fournal, 25, 389.

Fisher, M. L., Nutter, D. O., Jacobs, W., and Schlant, R. C. (1973). Haemodynamic responses to isometric exercise (handgrip) in patients with heart disease. British Heart fournal, 35, 422.

Gibson, T. C., Madry, R., Grossman, W., McLaurin, L. P., and Craige, E. (1974). The A wave of the apexcardiogram and left ventricular diastolic stiffness. Circulation, 49, 441.

Ginn, W. M., Sherwin, R. W., Harrison, W. K., and Baker, B. M. (1967). Apexcardiography: use in coronary heart disease and reproducibility. American Heart fournal, 73, 168.

Gorlin, R., and Gorlin, S. G. (1951). Hydraulic formula for calculation of the area of the stenotic mitral valve, other cardiac valves, and central circulatory shunts. American Heart fournal, 41, 1.

Grossman, W., McLaurin, L. P., Saltz, S. B., Paraskes, J. A., Dalen, J. E., and Dexter, L. (1973). Changes in the inotropic state of the left ventricle during isometric exercise. British Heart fournal, 35, 697.

Helfant, R. H., DeVilla, M. A., and Meister, S. G. (1971). Effect of sustained isometric handgrip exercise on left ventricular performance. Circulation, 44, 982.

Hume, L., Irving, J. B., and Reuben, S. R. (1974). Effects of beta blockade on the praecordial accelerogram (abstract). Scottish Medical fournal, 19, 200.

Kivowitz, C., Parmley, W. W., Donoso, R., Marcus, H., Ganz, W., and Swan, H. J. C. (1971). Effects of isometric 
exercise on cardiac performance. The grip test. Circulation, 44, 994.

Krayenbuehl, H. P., Rutishauser, W., Schoenbeck, M., and Amende, I. (1972). Evaluation of left ventricular function from isovolumic pressure measurements during isometric exercise. American fournal of Cardiology, 29, 323.

Ludbrook, P., Karliner, J. S., and O'Rourke, R. A. (1974). Effects of submaximal isometric handgrip on left ventricular size and wall motion. American fournal of Cardio$\log y, 33,30$.

Luisada, A. A. (1962). (Ed.) Cardiology, an Encyclopedia of the Cardiovascular System. Vol. 2. Suppl. on Methods, part 3. McGraw-Hill, New York.

Mounsey, P. (1957). Praecordial ballistocardiography. British Heart fournal, 19, 259.

Mounsey, P. (1959). Praecordial pulsations in relation to cardiac movement and sounds. British Heart fournal, 21, 457.

Parker, J. O., Di Giorgi, S., and West, R. O. (1966). A hemodynamic study of acute coronary insufficiency precipitated by exercise. With observations on the effects of nitroglycerin. American fournal of Cardiology, 17, 470.

Quinones, M. A., Gaasch, W. H., Waisser, E., Thiel, H. G., and Alexander, J. K. (1974). An analysis of the left ventricular response to isometric exercise. American Heart fournal, 88, 29.

Reuben, S. R., and Littler, W. A. (1973). Praecordial accelerometry: an indirect assessment of left ventricular performance. European fournal of Clinical Investigation, 3, 324.

Rios, J. C., and Massumi, R. A. (1965). Correlation between the apex cardiogram and left ventricular pressure. American fournal of Cardiology, 15, 647.

Rosa, L. M., Constantino, J. P., Reich, R., Karsak, N., and Zezmer, B. (1961). The precordial accelerogram in normal subjects and non-cardiac patients. Experimental Medicine and Surgery, 19, 207.

Rosa, L. M., and Kaplan, M. (1960). Experimental studies on the effect of some cardiovascular drugs on the precordial acceleration tracing. Experimental Medicine and Surgery, 18, 319.

Siegel, W., Gilbert, C. A., Nutter, D. O., Schlant, R. C., and Hurst, J. W., (1972). Use of isometric handgrip for the indirect assessment of left ventricular function in patients with coronary atherosclerotic heart disease. American fournal of Cardiology, 30, 48.

Stefadouros, M. A., Grossman, W., El Shahawy, M., and Witham, A. C. (1974). The effect of isometric exercise on the left ventricular volume in normal man. Circulation, 49, 1185.

Voigt, G. C., and Friesinger, G. C. (1970). The use of apexcardiography in the assessment of left ventricular diastolic pressure. Circulation, 41, 1015.

Wiener, L., Dwyer, E. M., and Cox, J. W. (1968). Left ventricular hemodynamics in exercise-induced angina pectoris. Circulation, 38, 240.

Requests for reprints to Dr. S. R. Reuben, Department of Medicine, Western General Hospital, Edinburgh EH4 2XU. 